Original Research Paper

\title{
ANTI-BACTERIAL ACTIVITY OF ETHANOL EXTRACT OF INDIAN BORAGE (Coleus amboinicus) LEAVES AGAINST BACILLUS CEREUS
}

\section{Maya Sari Mutia*, Elvia Annisa, Suhartomi}

\author{
Faculty of Medicine, Universitas Prima Indonesia, Medan, Indonesia
}

\section{"Email Corresponding: \\ mayasarimutia11@gmail.com}

Page : $30-34$

\section{Keywords:}

Bacillus cereus, Coleus amboinicus, ethanol, extract

\section{Kata Kunci :}

Bacillus cereus, Coleus amboinicus, etanol, ekstrak

\begin{abstract}
Bacillus cereus is aerobic, positive gram, and spore-forming bacilli bacteria. The enterotoxin of this bacteria can cause food poisonous that manifest as diarrhea and vomitus. Some previous study has been performed to explore the antibacterial effect of Indian borage leaf, but none of them were explore the antibacterial effect of Indian borage against Bacillus cereus. Hence this study was design to explore the antibacterial activity of ethanol extract of Indian borage against Bacillus cereus. This was an experimental study with post only control group design. Ethanol extract was extracted by maceration methods and antibacterial activity against Bacillus cereus was evaluated by disc diffusion methods. The obtained ethanol extract was dissolved into some concentraions (1 $\mathrm{g} / \mathrm{ml}, 0.8 \mathrm{~g} / \mathrm{ml}, 0.6 \mathrm{~g} / \mathrm{ml}, 0.4 \mathrm{~g} / \mathrm{ml}, 0.2 \mathrm{~g} / \mathrm{ml}$ ). Data was analysed by One Way ANOVA and followed by Post hoc Test Tukey HSD using SPSS 25. Ethanol extract of Coleus amboinicus showed significant difference at the two highest concentration group against the lowest concentration $(P-$ Value $<0.05)$. The average of inhibition zone diameter from the lowest $(0.2 \mathrm{gr} / \mathrm{ml})$ and highest $(1.0$ $\mathrm{gr} / \mathrm{ml}$ ) concentration were $14.87 \mathrm{~mm}$ and $31.50 \mathrm{~mm}$, respectively. Overall, ethanol extract of Indian borage leaves had potential antibacterial activity against Bacillus cereus. This antibacterial activity increase followed by the increase of the concentration.
\end{abstract}

ABSTRAK
Bacillus cereus merupakan bakteri aerob, gram positif, dan basil pembentuk
spora. Enterotoksin bakteri ini dapat menyebabkan keracunan makanan yang
bermanifestasi sebagai diare dan muntah. Beberapa penelitian sebelumnya telah
dilakukan untuk mengetahui efek antibakteri daun bangun-bangun, namun tidak
satupun dari penelitian tersebut yang mengeksplorasi efek antibakteri dari daun
bangun-bangun terhadap Bacillus cereus. Oleh karena itu penelitian ini dirancang
untuk mengetahui aktivitas antibakteri ekstrak etanol daun bangun-bangun
terhadap Bacillus cereus. Penelitian ini merupakan penelitian eksperimental
dengan desain post only control group design. Ekstrak etanol diekstraksi dengan
metode maserasi dan aktivitas antibakteri terhadap Bacillus cereus dievaluasi
dengan metode difusi cakram. Ekstrak etanol yang diperoleh dilarutkan ke dalam
beberapa konsentrasi $(1 \mathrm{~g} / \mathrm{ml}, 0,8 \mathrm{~g} / \mathrm{ml}, 0,6 \mathrm{~g} / \mathrm{ml}, 0,4 \mathrm{~g} / \mathrm{ml}, 0,2 \mathrm{~g} / \mathrm{ml})$. Data
dianalisis dengan One Way ANOVA dan dilanjutkan dengan Post hoc Test
Tukey HSD menggunakan SPSS 25. Ekstrak etanol Coleus amboinicus
menunjukkan perbedaan yang nyata pada dua kelompok konsentrasi tertinggi
terhadap konsentrasi terendah (Nilai P <0,05). Rata-rata diameter zona hambat
dari konsentrasi terendah (0,2 gr / ml) dan tertinggi (1,0 gr / ml) berturut-turut
adalah 14,87 mm dan 31,50 mm. Secara keseluruhan ekstrak etanol daun bangun-
bangun memiliki potensi aktivitas antibakteri terhadap Bacillus cereus.
Peningkatan aktivitas antibakteri ini diikuti dengan peningkatan konsentrasi.

\section{Published by:}

Tadulako University, Managed by Faculty of Medicine. Email: healthytadulako@gmail.com Phone (WA): +6285242303103 Address:

Jalan Soekarno Hatta Km. 9. City of Palu, Central Sulawesi, Indonesia and vomitus, however the vomitus is dominant. If the bacteria was digested, the clinical presentation will be appeared within 1-6 hours and persistent less than 24 hours. The clinical manifestations are 
nausea, vomitus, and abdominal pain, and diarrhea. According the data from Sentra Informasi Keracunn Nasional at 2014, that reported 855 cases of food poisonous caused by Bacillus cereus, Clostridium botulinum, Staphylococcus aureus, Salmonella sp, and Escherichia coli, however the number of the cases did not represent the exact number of cases due to some unreported mild cases ${ }^{1}$.

It becomes important to looking for natural resource to optimize therapy for Bacillus cereus infection. Indian borage that also known as "bangun-bangun" that had science name as Coleus amboinicus. This leaf is widely used as traditional medicine due to various health benefits. Several studies have been evaluated the antimicrobial activity against some fungal or bacteria. The essential oil of this herb is proofed not only has antibacterial activity against Bacillus subtilis, Eschericia coli, Staphylococcus aureus, Staphylococcus epidermidis, Pseudomonas aureginosa, Proteus vulgaris, Bacillus subtiliis, Staphylococcus mutans, and Serratia marencens, but also antifungal activity against Candida albicans and Candida tropicalis ${ }^{2-5}$

Although, the most of previous studies had explore antibacterial activity from essential oil or extract of Indian borage. However, these studies didn't explore antibacterial activity from ethanol extract of Indian Borage against Bacillus cereus, previous study had been explore the bacterial effect but it didn't explore antibacterial activity against Bacillus cereus and almost none study explore antibacterial activity from ethanol extract. Based on the information above, this study was design to explore the antibacterial activity of ethanol extract of Indian borage against Bacillus cereus.

\section{METHODS}

This study was an experimental study with post only control group design. Antibacterial activity evaluated by disc diffusion methods. This study was performed in Microbiology Laboratory of Medical Faculty, Universitas Prima Indonesia on September 2019. The scheme of this study was sumirazed in the figure 1 .

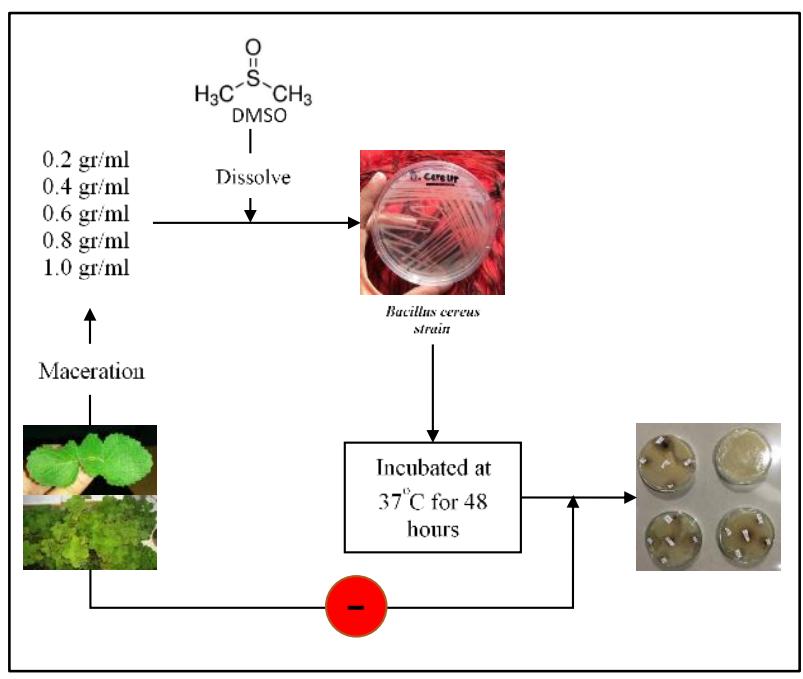

Figure 1. Scheme of Antibacterial Effect of Indian Borage Leaves Extract against Bacillus cereus

\section{Indian borage or "Bangun Bangun"} Leaves was obtained from a traditional market in the Medan City. On other hand, Bacillus cereus was strain of bacteria that have been cultured in the laboratory. Meanwhile, all instrument which were used in this study was sterilized by Autoclave at $121^{\circ} \mathrm{C}$ for 15 minutes ${ }^{6,7}$.

Indian borage leaves were washed, then they were dried under at $40^{\circ} \mathrm{C}$ for 3 days. After the leaves were mesh into simplicia powder by blended them. Moreover, amount of 40 gr simplicia power was macerated by soaked into $500 \mathrm{ml}$ Methanol and this maceration was repeated two times. It was filtered and the filtrate was evaporated by rotary evaporator that called as concentrated form. The concentrated form was dissolved by DMSO (Dimethyl sulfoxide) into several concentration. Amount of $2 \mathrm{~g}, 4 \mathrm{~g}, 6 \mathrm{~g}, 8 \mathrm{~g}$, and $10 \mathrm{~g}$ concentrated form was dissolved into $10 \mathrm{ml}$ to form $0.2 \mathrm{gr} / \mathrm{ml}, 0.4 \mathrm{gr} / \mathrm{ml}, 0.6 \mathrm{gr} / \mathrm{ml}$, $0.8 \mathrm{gr} / \mathrm{ml}$, and $1 \mathrm{gr} / \mathrm{ml}$ concentration, respectively ${ }^{7}$.

Bacillus cereus was obtained from the Microbiology Laboratory of Medical Faculty in Universitas Prima Indonesia. Bacillus cereus was cultured on agar slants. An inoculum of the bacteria was cultured into Nutrient Broth (NB) in tube reaction then it was homogenized and incubated at $37^{\circ} \mathrm{C}^{7}$. 
The antibacterial activity was evaluated by dis diffusion methods. At the beginning of assay, amount of $2.8 \mathrm{~g}$ of NA (Nutrient Agar) Powder into $100 \mathrm{ml}$ aquadest then it was homogenized by hot plate stirrer. After that, it was sterilized using autoclave at $121{ }^{\circ} \mathrm{C}$ for 15 minutes. The NA was pour into some plates for antimicrobial assay. Bacillus cereus strain from Nutrient broth was swabbed into NA Plate surface by cotton swab. After that, placed either dissolved extract disc or blank disc into the NA Plate surface, then All NA Plates were incubated at $37^{\circ} \mathrm{C}$ for 48 hours. After 48 hours, the NA Plate would showed clear zone around the disc that also known as inhibition zone, its diameter was measured in millimeters (mm) by caliper ${ }^{6,7}$.

All data were analyzed using descriptive and inferential statistic. Descriptive analysis was looking for central tendency and disperse of inhibition zone diameter based on their concentration followed by normality test using Shapiro-wilk. If the data distribution was normal, the data was analyzed by one way ANOVA, instead of Kruskall-Wallis.

\section{RESULT AND DISCUSSION}

The result of antibacterial activity from ethanol extract of Indian borage leaves was shown in the figure 2 and the result of statistical analysis was shown by the table 1 .
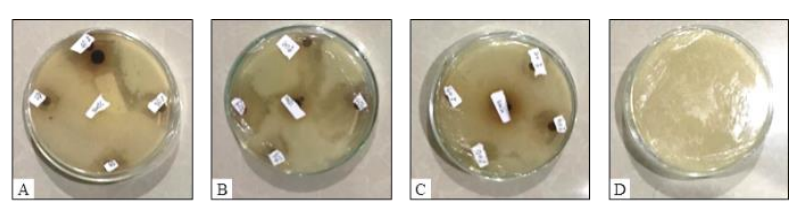

Figure 2. Result of antibacterial Assay from Ethanol extract of Indian borage leaves

The figure 2 was shown the petri dish that used to evaluate the antibacterial activity of Indian borage leaves against Bacillus cereus. The first, second, and third repetition were marked as $\mathrm{A}, \mathrm{B}$, and $\mathrm{C}$, respectively.

Meanwhile, the Marked D Figure above was NA Plate without bacterial strains (blank plate).

Table 1. Inhibition Zone Diameter from Each concentrations of Ethanol extract of Indian borage leaves against Bacillus cereus

\begin{tabular}{|c|c|c|c|}
\hline \multirow[t]{2}{*}{ Concentration } & $\begin{array}{l}\text { Inhibi } \\
\text { Diame }\end{array}$ & Inhibition Zone & \multirow[t]{2}{*}{ P-Value* } \\
\hline & Mean & SD & \\
\hline $0.2 \mathrm{gr} / \mathrm{ml}$ & 14.87 & 1.46 & \multirow{5}{*}{0.01} \\
\hline $0.4 \mathrm{gr} / \mathrm{ml}$ & 19.17 & 3.15 & \\
\hline $0.6 \mathrm{gr} / \mathrm{ml}$ & 20.10 & 3.34 & \\
\hline $0.8 \mathrm{gr} / \mathrm{ml}^{* *}$ & 28.07 & 6.93 & \\
\hline $1.0 \mathrm{gr} / \mathrm{ml}^{* *}$ & 31.50 & 6.88 & \\
\hline
\end{tabular}

Based on table 2 above, the increase of concentration showed a significant change in inhibition zone. Furthermore, the post hoc test showed that up to $0.8 \mathrm{mg} / \mathrm{ml}$ of extract showed a significant difference against the lowest concentration $(0.2 \mathrm{gr} / \mathrm{ml})$

Moreover, the inhibition zone that was form by the antibacterial assay was measured by caliper and the result of analysis was shown by the following table ${ }^{8}$.

Table 2. Degree of Antimicrobial Activity Based on Greenwood Classification

Average of

Inhibition Zone

Diameter

\begin{tabular}{ll}
\hline$>20 \mathrm{~mm}$ & Potent \\
\hline $16-20 \mathrm{~mm}$ & Moderate \\
\hline $11-15 \mathrm{~mm}$ & Weak \\
\hline$<10 \mathrm{~mm}$ & None \\
\hline
\end{tabular}

The table 2 showed that there are significant difference at the two highest concentration group against the lowest concentration. According to greenwood classification, the two highest concentration of 
the extract shown potent antibacterial activity due to the average of their inhibition zone diameter wider than $20 \mathrm{~mm}$. On the other hand, lower concentrations which were 0.4 $\mathrm{gr} / \mathrm{ml}$ and $0.6 \mathrm{gr} / \mathrm{ml}$ shown moderate antibacterial activity and the lowest concentration was shown weak antibacterial activity. The following table was shown degree of antimicrobial activity ${ }^{8}$.

Although there was none study that explore the antibacterial activity of Indian borage leaf against Bacillus cereus. However, there are several previous studies have been performed to explore the antibacterial activity against other positive gram bacteria. The following table show the previous studies as the comparison.

Several studies has been performed to investigate the antibacterial effect of the Indian borage leaf. However, antibacterial activity from ethanol extract shown similar properties to other type of bacteria. It seem from their average of Inhibition Zone Diameter in each concentration. Although, the recent study shown inhibition zone around 30 $\mathrm{mm}$ at the higher concentration, the wider inhibition zone may due to the higher concentrations that were used in the recent study than in the previous study. The antibacterial activity of Indian borage leaf may be due to the presence of some phytochemicals like phenolic compound which has antimicrobial activity $5,9,10$

\section{CONCLUSION}

Overall, ethanol extract of Indian borage leaves had potential antibacterial activity against Bacillus cereus. This antibacterial activity increase followed by the increase of the concentration. The highest $(1.0 \mathrm{gr} / \mathrm{ml})$ and lowest $(0.2 \mathrm{gr} / \mathrm{ml})$ concentration was shown potent $(31.50 \mathrm{~mm})$ and weak $(14.87 \mathrm{~mm})$ antimicrobial activity, respectively.

\section{ACKNOWLEDGMENT}

Thank you to all those who have helped the author in completing this research

\section{REFERENCES}

1. BPOM RI. Keracunan Pangan Akibat Bakteri Patogen Bag.II. Sentra Inf Keracunan Nas Badan Pengawas Obat dan Makanan RI. Published online 2014:1-5.

2. Erny Sabrina MN, Razali M, Mirfat AHS, Mohd Shukri MA. Antimicrobial activity and bioactive evaluation of Plectranthus amboinicus essential oil. Am J Res Commun. 2014;2(212):121127.

3. Santos FAV, Serra CG, Bezerra RJAC, et al. Antibacterial activity of Plectranthus amboinicus Lour (Lamiaceae) essential oil against Streptococcus mutans. Eur J Integr Med. 2016;8(3):293-297. doi:10.1016/j.eujim.2015.11.021

4. Vasconcelos SECB, Melo HM, Cavalcante TTA, et al. Plectranthus amboinicus essential oil and carvacrol bioactive against planktonic and biofilm of oxacillin- and vancomycin-resistant Staphylococcus aureus. BMC Complement Altern Med. 2017;17(1):19. doi:10.1186/s12906-017-1968-9

5. Devi NN, Dheeban P, Femina W, Paramasivam T. From the Medicinal Plant Plectranthus Amboinicus. Comp A J Comp Educ. 2012;12(1).

6. Michiko M, Manalu CV, Mutia MS. Uji Efektivitas Ekstrak Etanol Kulit Jeruk Manis (Citrus sinensis) terhadap Bakteri Propionobacteriu acnes. (Jurnal Ilm Mhs Kesehat Masyarakat). 2020;5(1). doi:10.37887/jimkesmas.v5i1.10552

7. Diana S MP, Annisa E, Mutia MS. Uji Efektivitas Ekstrak Methanol Daun Bangun-Bangun (Coleus amboinicus) terhadap jamur Candida albicans. (Jurnal Ilm Mhs Kesehat Masyarakat). 2020;5(1):34-37. doi:10.37887/jimkesmas.v5i1.10747

8. Suandy, Girsang E, Nasution AN, Lister INE. Analysis of Protein Content, Spectrophotometry FT-IR, and 
Antibacterial Effects of Earthworm (Eudriluseugenia). Am Sci Res J Eng Technol Sci. 2020;63(1):94-101.

9. Kumar P, Sangam, Kumar N. Plectranthus Amboinicus: a Review on Its Pharmacological and, Pharmacognostical Studies. Am $J$ Physiol Biochem Pharmacol. 2020;10(2):55.

doi:10.5455/ajpbp.20190928091007

10. Maldonado D, Subramanian G, Kurup R, Ansari AA. Antifungal Activity and Phytochemical Screening of Cymbopogon citratus, Cajanus cajan and Plectranthus amboinicus Leaves Collected in Guyana, South America. Int $J \quad$ Pathog Res. 2020;5(1):1-9. doi:10.9734/ijpr/2020/v5i130122 